\title{
Thoracic Vertebral Hemangioma Causing Paraplegia in Klippel-Trenaunay-Weber Syndrome: Case Report
}

\author{
Klippel-Trenaunay-Weber Sendromunda Paraplejiye Neden Olan \\ Vertebral Hemanjiyom: Olgu Sunumu
}

\author{
Ozerk OKUTAN ${ }^{1}$, Timur YILDIRIM ${ }^{1}$, Serdar ISIK ${ }^{2}$, Berna GOKCE ${ }^{1}$, Barıs SAYGILI ${ }^{1}$, Ethem BESKONAKLI ${ }^{1}$ \\ ${ }_{1}^{1}$ Ankara Ataturk Education and Research Hospital, Department of Neurosurgery, Ankara, Turkey \\ ${ }^{2}$ Ordu University, Faculty of Medicine, Department of Neurosurgery, Ordu, Turkey
}

Corresponding Author: TimurYILDIRIM / E-mail: mdtimur@hotmail.com

\begin{abstract}
Vertebral hemangiomas are the most common tumours of the vertebral column. Generally, these tumours are asymptomatic but some patients complain of back pain and develop neurologic symptoms due to extraosseous extension. Vertebral hemangiomas can extend extradurally causing neurological impairment as a result of compression of the spinal cord and nerve roots. Vertebral hemangiomas may be multiple and detectable as a component of the Klippel-Trenaunay-Weber syndrome. Although this syndrome consists of deep venous thrombosis, lymphatic anomalies, cutaneous capillary malformations, and hypertrophy of soft tissue and bone on extremities, its clinical presentation may be very variable. We present a unique case of vertebral hemangioma causing spinal cord compression due to the extradural extension that also had deep venous thrombosis, hematuria, hypophyseal cyst and ventricle asymmetry, diagnosed as the Klippel-Trenaunay-Weber syndrome.

KEYWORDS: Thoracic vertebra, Hemangioma, Cord compression, Klippel-Trenaunay-Weber syndrome

\section{öz}

Vertebral hemanjiyomlar vertebral kolonun en sık görülen tümörleridir. Genel olarak bu tümörler asemptomatikdir ancak bazı hastalarda sırt ağrısı ve kemik dışı yayılıma bağlı nörolojik defisitler görülebilir. Bu olgularda hemanjiyomlar dura dışı olarak yayılır ve sırt ağrısına, radikülopatiye, spinal kord ve sinir köklerinin basısı sonucu ilerleyici veya ani parapareziye neden olur. Vertebral hemanjiyomlar çoklu ve KlippelTrenaunay Weber sendromu ile ilişkili olabilirler. Bu sendromda derin venöz tromboz, lenfatik anomaliler, kutanöz apiller malformasyonlar, ekstremitelerde yumuşak doku ve kemik hipertrofisi bulunsa da klinik görünüm oldukça değişiklik göstermektedir. Dura dışı yayılımına bağlı olarak spinal kordu basılayan aynı zamanda derin venöz tromboz, hematüri, hipofizyel kist ve ventrikül asimetrisi bulunan ve KlippelTrenaunay-Weber sendromu olarak düşündüğümüz oldukça nadir görülen vertebral hemanjiyom vakasını sunmaktayız.
\end{abstract}

ANAHTAR SÖZCÜKLER: Torakal vertebra, Hemanjiyom, Kord basısı, Klippel-Trenaunay-Weber sendromu

\section{INTRODUCTION}

Vertebral hemangioma (VH) is a benign vascular tumour and developmental hamartoma with no mitotic activity (5). In autopsy series it has been seen with a prevelance of $11 \%$ and accounts for $28 \%$ of all skeletal hemangiomas $(6,9)$. $\mathrm{VHs}$ are usually multiple and can be a component of the Klippel-Trenaunay-Weber syndrome (3). Venous thrombosis is usually seen as a complication in this syndrome (4). VHs rarely causes neurological symptoms but this condition should be considered in the differential diagnosis when a patient presents with progressive weakness of extremities. Neurological symptoms occur when lesions extend to involve the neural arch due to fracture of the involved vertebra, hemorrhage, hypertrophy, spinal cord ischemia, and extradural mass compression $(10,11)$. The Klippel-TrenaunayWeber syndrome should be considered in young patients with multiple hemangiomas.

\section{CASE REPORT}

A 30-year-old man with paraplegia was admitted with a complaint of rapidly progressive weakness and numbness in his legs for the past month. His past medical history consisted of hematuria and a deep venous thrombosis surgery 2 months before the weakness of his legs. On physical examination, there was full weakness of both lower extremities and loss of sensation. The Babinski sign was bilaterally positive. The patient had paraplegia but no urinary or anal incontinence. There was a hyperpigmented lesion on the patient's right leg. Laboratory findings revealed microscopic hematuria.

$X$-rays of the thoracic spine were reported as degenerative changes and trabeculated pattern of the T5 vertebra. Computerized tomography (CT) scan of the thoracic spine showed coarse trabeculation within the T5 vertebra involving both anterior and posterior vertebral elements (Figure 1). CT of the thoracic spine showed multiple hemangiomas on the posterior side of the left 3rd and 4th costae (Figure 2). 
Magnetic resonance imaging (MRI) of the thoracic vertebral column revealed a T5-level soft-tissue mass that involved both the anterior and posterior vertebral elements, extended into the epidural space, caused expansion of the laminae and pedicles on both sides, and significantly compressed the spinal cord (Figure 3). On cranial MR studies, the anterior horn of the left lateral ventricle was significantly dilated compared to the right side (Figure 4A) and there was cyst formation on the left posterior part of hypophysis with the stalk deviated to the right side (Figure 4B).

Lower extremity venous Doppler ultrasound revealed intraluminal echogenic thrombosis material in the right superficial femoral vein, and spontaneous reflux blood flow on both left and right main femoral veins.

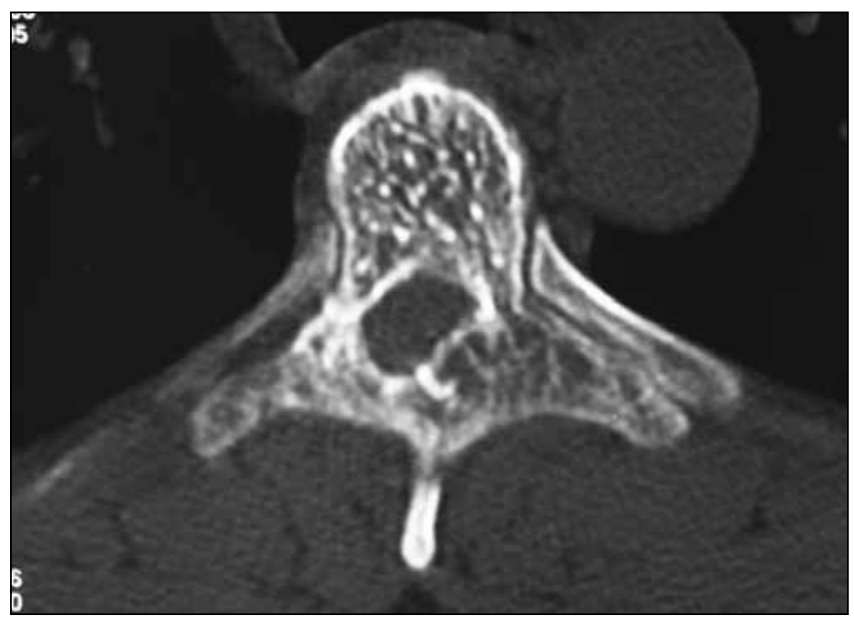

Figure 1: Coarse trabeculation within the T5 vertebra involving both anterior and posterior vertebral elements on CT imaging.

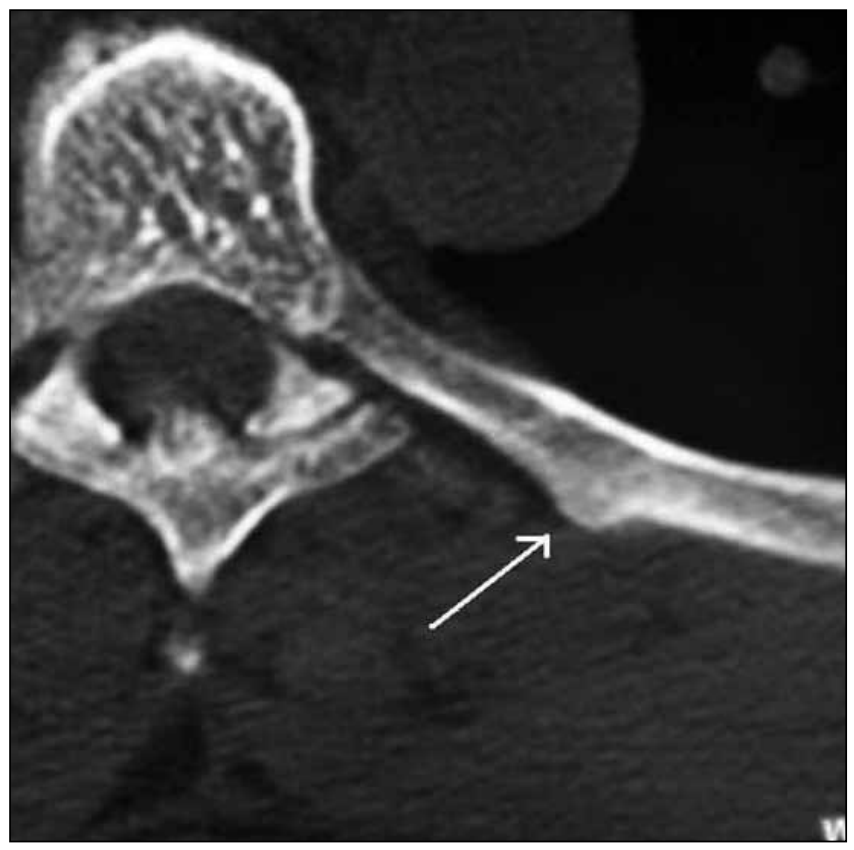

Figure 2: Thoracic CT image shows a hemangioma causing expansion on the posterior side of the left 3th costae.
C-arm fluoroscopy was used to determine the throacal level and paraspinal muscles were dissected at the T4-5-level with a posterior approach. Posterior decompression was performed by totally removing the T5 vertebral laminae. The posterior epidural tumoral tissue was resected as much as possible. The operation ended uneventfully. Histopathological examination of the resected mass showed vascular slits and endothelium proliferation indicating that the lesion was a $\mathrm{VH}$ and showed no signs of malignancy. Movement was observed on both toes on the first day after surgery and the patient underwent physiotherapy. Within two weeks of physiotherapy, the patient showed a rapid development and was discharged with $3 / 5$ strength of lower extremities.

\section{DISCUSSION}

VHs are common entities that rarely involve the posterior vertebral elements as they are usually located in the vertebral corpus. VHs are commonly seen in the thoracic vertebrae and are asymptomatic. VHs may cause back pain in only $1 \%$ of cases. They should be considered in the differential diagnosis as they may rarely cause neurological symptoms and compressive myelopathy (1). VHs may be multiple and associated with the Klippel-Trenaunay-Weber syndrome. The Klippel-Trenaunay syndrome (KTS) was first described by Klippel and Trenaunay in 1900. This disorder was described with the three main symptoms of cutaneous hemangioma, varicose veins and bone and soft tissue hypertrophy, known as a triad affecting one or more limbs (3). Parkes and Weber added the arteriovenous fistula to this syndrome. This form of KTS was called Klippel-Trenaunay-Weber syndrome. In a study at the Mayo Clinic, 252 patients with KTS were evaluated. Varicosities were seen in $72 \%$, portwine stain in $98 \%$ and limb hypertrophy in $67 \%$ (7). These are classified

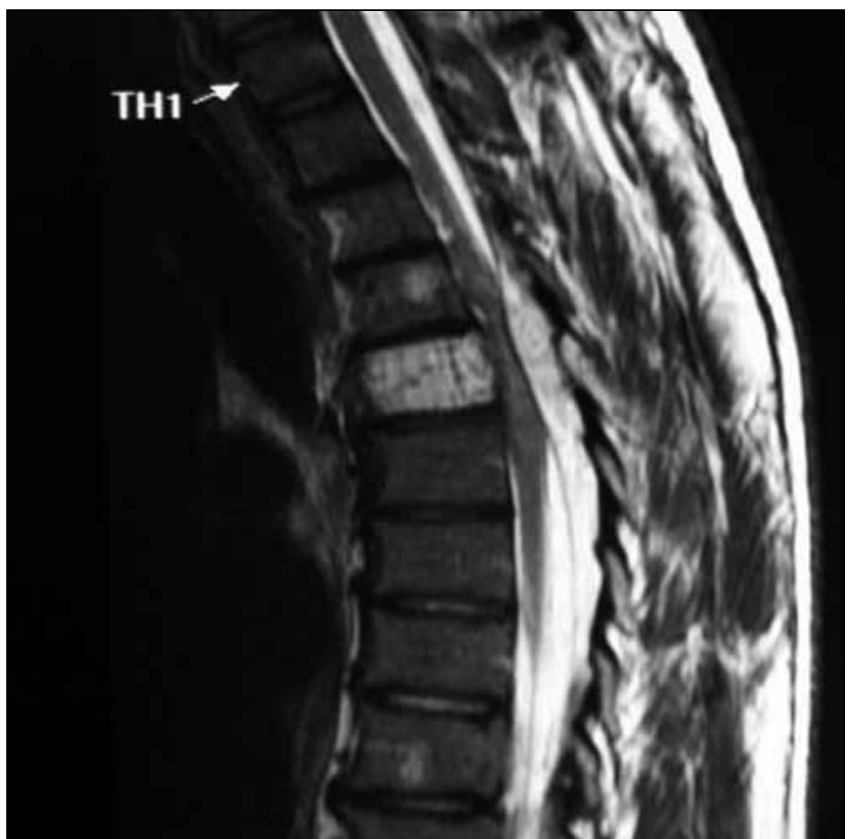

Figure 3: On MRI soft-tissue mass that involved three columns extended into the epidural space. 

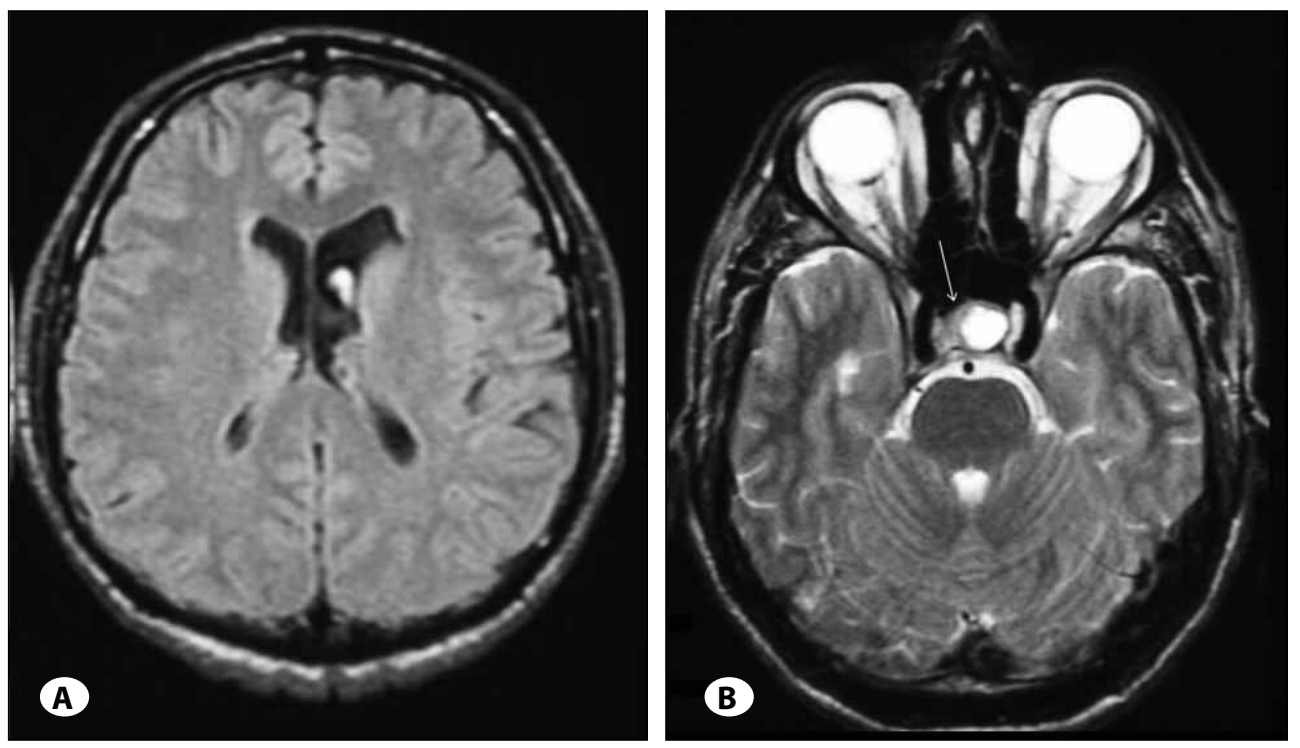

Figure 4: A) On cranial MR studies, anterior horn of the left lateral ventricule was significantly dilated comparing to the right side. B) On cranial MRI a cyst formation on the left posterior part of hypophysis and the stalk was deviated to the right side.

as major findings with arteriovenous fistula. Although most patients demonstrate all four major findings, the clinical presentation is variable and the cause is most likely genetic in view of recent discoveries of gene mutations in KTWS patients (2). Our patient had no limb hypertrophy but there was a hyperpigmented lesion on the right leg, a hemangioma on the thoracal vertebra and multiple hemangiomas on the 3rd and 4th costae.

Minor findings of KTWS patients are hematuria, thrombophlebitis, visceral vascular malformations involving the liver, spleen, kidney and bladder, rectal bleeding, spinal arteriovenous fistulas, asymmetric facial hypertrophy, cataracts, glaucoma, micro or macrocephaly, seizures or mental retardation, congestive heart failure, intestinal lymphangiectasia, polydactyly, syndactyly or macrodactyly, length and diameter discrepancy between two extremities, and lymph edema $(7,8)$. The patient we reported had multiple hemangiomas involving vertebra and costae, deep venous thrombosis, a hyperpigmented lesion on the right leg, microscopic hematuria, a hypophyseal cystic structure pushing the stalk to the right side and ventricular asymmetry in the brain.

\section{CONCLUSION}

KTWS is a rare and complex disease. As a component of this syndrome, vertebral hemangiomas are usually asymptomatic but can cause rapid and progressive neurologic symptoms that are usually insidious in onset. In conclusion, care should be taken to determine other clinical components in KTWS and multisystematic evaluation is very important to determine appropriate treatment modalities.

We have not had any grants or funds in support of the study.

\section{REFERENCES}

1. Bandiera S, Gasbarrini A, De lure F, Cappuccio M, Picci P, Boriani: Symptomatic vertebral hemangioma: The treatment of 23 cases and a review of the literature. Chir Organi Mov $87: 1-15,2002$
2. Boutarbach M, Ben Salem D, Gire L, Giroud M, Bejot Y, Ricolfi F: Multiple cerebral and spinal cord cavernomas in KlippelTrenaunay-Weber syndrome. Journal of Clinical Neuroscience 17(8):1073-1075, 2010

3. Feuerman T, Dwan PS, Young RF:Vertebrectomy for treatment of vertebral hemangioma without preoperative embolization. Case report. J Neurosurg 65:404-406, 1986

4. Gianlupi A, Harper RW, Dwyre DM, Marelich GP: Recurrent pulmonary embolism associated with Klippel-TrenaunayWeber Syndrome. Chest 115: 1199-1201, 1999

5. Harrison MJ, Eisenberg MB, Ullman JS, Oppenheim JS, Camins $M B$, Post KD: Symptomatic cavernous malformations affecting the spine and spinal cord. Neurosurgery 37(2):195-204, 1995

6. Huvos AG: Hemangioma, lymphangioma, angiomatosis/ lymphangiomatosis, glomus tumor. In: Huvos AG (ed), Bone Tumors: Diagnosis, Treatment and Prognosis, 2nd edn. Philadelphia: Saunders, 1991:553-578

7. Jacob AG, Driscoll DJ, Shaughnessy WJ, et al: KlippelTrenaunay Syndrome: Its spectrum and management. Mayo Clinic Proc 73:28-36, 1998

8. Jafri SZ, Bree RL, Glazer GM, et al: Computed tomography and ultrasound findings in Klippel-Trenaunay syndrome. Journal of Computer Assisted Tomography 7:457-460, 1983

9. Mirra JM: Vascular tumors. In: Mirra JM (ed) Bone Tumors: Clinical, Radiologic, and Pathologic Considerations. Philadelphia: Lea and Febiger 1989:1340-1478

10. Schwartz DA, Nair S, Hershey B, Wilkelmann AC, Finkelstein SD: Vertebral arch hemangioma producing spinal cord compression in pregnancy-diagnosis by magnetic resonance imaging. Spine 14:888-890, 1989

11. Tekkok IH, Acikgoz B, Saglam S, et al: Vertebral hemangioma symptomatic during pregnancy- report of a case and review of the literature. Neurosurgery 32:302-306, 1993 